Authors' contribution/

Wkład autorów:

A. Zaplanowanie badań/

Study design

B. Zebranie danych/

Data collection

C. Analiza statystyczna/

Statistical analysis

D. Interpretacja danych/

Data interpretation

E. Przygotowanie tekstu/

Manuscript preparation

F. Opracowanie

piśmiennictwa/

Literature search

G. Pozyskanie funduszy/

Funds collection
ISSN 2083-3725
Volume 10, No. 1, 2017

\section{THE ROLE OF THE INSTITUTIONAL SUPPORT OF THE ENTREPRENEUR IN THE REGION IN THE DEVELOPMENT OF INVESTMENT ATTRACTIVENESS (THE EXAMPLE OF POLAND)}

\section{ROLA WSPARCIA INSTYTUCJONALNEGO PRZEDSIĘBIORCY W REGIONIE W KSZTAŁTOWANIU ATRAKCYJNOŚCI INWESTYCYJNEJ (NA PRZYKŁADZIE POLSKI)}

\author{
Agnieszka Komor \\ University of Life Sciences in Lublin \\ Uniwersytet Przyrodniczy w Lublinie
}

\section{ORIGINAL ARTICLE}

JEL code: 043, P48

Submitted:

December 2016

Accepted:

January 2017

Tables: 1

References: 62
Figures: 0

Komor A. (2017), The role of the institutional support of the entrepreneur in the region in the development of investment attractiveness (the example of Poland)/ Rola wsparcia instytucjonalnego przedsiębiorcy $w$ regionie $w$ kształtowaniu atrakcyjności inwestycyjnej (na przykładzie Polski). Economic and Regional Studies. Vol. 10, No. 1, pp. 21-35. https://doi.org/10.2478/ers-2017-0002

\section{Summary}

Subject and purpose of work: The subject of the work were business environment institutions as entities that affect the investment attractiveness of the region. The aim of the article was to identify and assess the role of business environment institutions in shaping the investment attractiveness of regions, with particular focus on park institutions and Regional Investor Service Centres.

Materials and methods: The article highlights the significance of institutional factors in shaping the investment attractiveness, in the light of both the national and foreign literature. In addition, a presentation was made of the results of the qualitative research involving an assessment of the content posted on the websites of selected institutions that provide support for entrepreneurs in the provinces. Results and conclusions: Business environment institutions constitute an important factor for potential investment attractiveness of the region through their impact on the possibilities of acquiring, storing, transforming and sharing of knowledge between different entities. Institutional coverage of the regions also affects the ability to create cooperation networks, including the formation of cluster initiatives. It has also been proven that there is a dependency between institutional resources of the region and its actual attractiveness.

Keywords: business environment institutions, investment attractiveness, region

\section{Streszczenie}

ORYGINALNY ARTYKUŁ NAUKOWY

Klasyfikacja JEL: 043, P48

Zgłoszony:

grudzień 2016

Zaakceptowany:

styczeń 2017

Tabele: 1

Rysunki: 0

Literatura: 62
Przedmiot i cel pracy: Przedmiotem pracy były instytucje otoczenia biznesu, jako podmioty wpływające na atrakcyjność inwestycyjną regionu. Celem artykułu była identyfikacja i ocena roli instytucji otoczenia biznesu w kształtowaniu atrakcyjności inwestycyjnej regionów, ze szczególnym uwzględnieniem instytucji parkowych oraz Regionalnych Centrów Obsługi Inwestora.

Materiały i metody: W artykule przedstawiono znaczenie czynników instytucjonalnych w kształtowaniu atrakcyjności inwestycyjnej w świetle literatury krajowej i zagranicznej. Ponadto dokonano prezentacji wyników badań jakościowych obejmujących ocenę treści zamieszczonych na stronach internetowych wybranych instytucji świadczących wsparcie dla przedsiębiorców w województwach.

Wyniki i wnioski: Instytucje otoczenia biznesu stanowią ważny czynnik potencjalnej atrakcyjności inwestycyjnej regionu poprzez wpływ na możliwości pozyskiwania, przechowywania, przekształcania i dzielenia się wiedzą pomiędzy różnymi podmiotami. Wyposażenie instytucjonalne regionów wpływa także na możliwość tworzenia sieci współpracy, w tym na powstawanie inicjatyw klastrowych. Wykazano również, że istnieje zależność pomiędzy zasobami instytucjonalnymi regionu a jego atrakcyjnością rzeczywistą.

Słowa kluczowe: instytucje otoczenia biznesu, atrakcyjność inwestycyjna, region

Address for correspondence/ Adres korespondencyjny: dr Agnieszka Komor, Uniwersytet Przyrodniczy w Lublinie, Akademicka 13, 20-950 Lublin, Polska; tel.: +48 814610061 wew.270,e-mail: agnieszka.komor@up.lublin.pl

Journal indexed in/ Czasopismo indeksowane w: AgEcon Search, AGRO, BazEkon, Index Copernicus Journal Master List, ICV 2015: 81,26; Polish Ministry of Science and Higher Education 2016: 9 points/ AgEcon Search, AGRO, BazEkon, Index Copernicus Journal Master List ICV 2015: 81,26; Ministerstwie Nauki i Szkolnictwa Wyższego 2016: 9 punktów. Copyright: (C) 2016 Pope John Paul II State School of Higher Education in Biała Podlaska, Agnieszka Komor. All articles are distributed under the terms of the Creative Commons Attribution-NonCommercial-ShareAlike 4.0 International (CC BY-NC-SA 4.0) License (http://creativecommons.org/licenses/by-nc-sa/4.0/), allowing third parties to copy and redistribute the material in any medium or format and to remix, transform, and build upon the material, provided the original work is properly cited and states its license. 


\section{Introduction}

The process of selecting business locations becomes more and more complicated because of the occurrence of significant changes of the discrete nature in the businesses' environment, and the rise of globalization and the progressing internationalization of companies, markets and regions. Business entities look for locations in the areas equipped with locational factors that enable entrepreneurs to achieve their set goals. Hence, it is of significance to search for the factors affecting the investment attractiveness of individual sites.

The aim of this article was to identify and assess the role of business environment institutions (BEI) in shaping the investment attractiveness of regions, with particular focus on Park institutions and Regional Investor Service Centres.

In the first part of the article, an attempt is made to highlight the significance of institutional factors in shaping the investment attractiveness, in the light of both the national and foreign literature. The second part involves presentation of the results of empirical research on selected business environment institutions operating in all provinces. The research includes websites of institutions providing support for entrepreneurs, including investors, in individual regions.

\section{Business environment institutions vs. investment attractiveness}

Investment attractiveness is associated with the ability to meet the expectations of investors that make investments in a particular region. The term investment attractiveness can be understood as "the ability to persuade investors to choose the region as their investment location" (Gawlikowska-Hueckel, Umiński 2000, p. 7). H. Godlewska-Majkowska proposes the division into actual and potential investment attractiveness. The actual investment attractiveness is understood as "the region's ability to absorb the financial and physical capital in the form of investments" (Godlewska-Majkowska 2008, p.18); while the potential investment attractiveness is " a set of regional locational advantages, which affect the achievement of the investor's objectives (e.g. costs of business, sales revenue, net profitability at the intended level)" (Godlewska-Majkowska 2008, p. 20).

In the knowledge-based economy, it is essential for the economic development of the country and the region, and for the competitiveness of enterprises, to increase the role of innovation, science and technology, the possibility to transform knowledge, the commercialization of scientific research regarding the knowledge that increases operational efficiency (The Knowledge-Based Economy 2006, p. 7). One of the essential conditions for an enterprise to achieve success is the ability to obtain sufficient quantity and quality of knowledge and information, as well as the ability to use and maintain it in a smart way (Mikuła 2006, p. 62-63). It should be noted, however, that companies do not operate in isolation,

\section{Wstęp}

Proces wyboru lokalizacji przedsiębiorstw ulega coraz większej komplikacji z powodu występowania $\mathrm{w}$ ich otoczeniu znacznych zmian o charakterze nieciągłym oraz narastania procesów globalizacyjnych i postępującej internacjonalizacji firm, rynków i regionów. Podmioty gospodarcze poszukują lokalizacji w miejscach wyposażonych w czynniki lokalizacyjne umożliwiające przedsiębiorcom osiąganie założonych celów. Stąd też istotne znaczenie ma poszukiwanie czynników wpływających na atrakcyjność inwestycyjną poszczególnych miejsc.

Celem niniejszego artykułu była identyfikacja i ocena roli instytucji otoczenia biznesu (IOB) w kształtowaniu atrakcyjności inwestycyjnej regionów, ze szczególnym uwzględnieniem instytucji parkowych oraz Regionalnych Centrów Obsługi Inwestora.

W pierwszej części artykułu dokonano próby ukazania znaczenia czynników instytucjonalnych w kształtowaniu atrakcyjności inwestycyjnej w świetle literatury krajowej i zagranicznej. W drugiej części zaprezentowano wyniki badań empirycznych dotyczących wybranych instytucji okołobiznesowych działających na terenie wszystkich województw. Badaniem objęto strony internetowe instytucji świadczących wsparcie dla przedsiębiorców, w tym inwestorów, w poszczególnych regionach.

\section{Instytucje otoczenia biznesu a atrakcyjność inwestycyjna}

Atrakcyjność inwestycyjną wiąże się ze zdolnością zaspokojenia oczekiwań inwestorów, dokonujących inwestycji w danym regionie. Pod pojęciem atrakcyjności inwestycyjnej można rozumieć „zdolność skłonienia inwestorów do wyboru regionu jako miejsca lokalizacji inwestycji" (Gawlikowska-Hueckel, Umiński 2000, s. 7). H. Godlewska-Majkowska proponuje podział na rzeczywistą i potencjalną atrakcyjność inwestycyjną. Przy czym rzeczywista atrakcyjność inwestycyjna rozumiana jest jako „zdolność regionu do absorpcji kapitału finansowego i rzeczowego $w$ formie inwestycji" (Godlewska-Majkowska 2008, s. 18); natomiast potencjalna atrakcyjność inwestycyjna to „zespót regionalnych walorów lokalizacyjnych, które maja wpływ na osiaganie celów inwestora (np. w postaci kształtowania się kosztów prowadzonej działalności gospodarczej, przychodów ze sprzedaży, rentowności netto na zakładanym poziomie)" (Godlewska-Majkowska 2008, s. 20).

W gospodarce opartej na wiedzy kluczowe znaczenie dla rozwoju gospodarczego kraju i regionu oraz konkurencyjności przedsiębiorstw ma zwiększenie roli innowacyjności, nauki i technologii, możliwości przekształcania wiedzy, komercjalizacji badań naukowych w zakresie wiedzy zwiększającej efektywność działalności (The Knowledge-Based Economy 2006, s. 7). Jednym z istotnych warunków osiągnięcia przez przedsiębiorstwo sukcesu jest umiejętność pozyskania odpowiedniej ilości i jakości wiedzy oraz informacji, a także zdolność jej wykorzystywania i podtrzymywania w sposób inteligentny (Mikuła 2006, s. 62-63). Należy przy tym zwrócić 
but are embedded in specific locations and socioeconomic contexts, which are also shaped by the political and institutional actors (Tödtling, Asheim, Boschma 2013).

Business environment institutions (BEIs) can constitute an important element of the knowledge acquisition, storage and sharing system. It is worth noting that regions differ in terms of institutional coverage, which affects the innovation and competitiveness of enterprises and the methods and performance of their knowledge acquisition. In this context, these institutions constitute an important factor for the region's potential investment attractiveness. Moreover, BEIs play an important role in stimulating the emergence of network links, including cluster-based ones, between partners in the region. This contributes to the increase in the competitiveness of business entities participating in this type of structures, and also has a positive effect on the location's attractiveness for potential investors (Jankowiak 2014, p. 270). It should be emphasized that clusters are an attractive formation for investments (including foreign ones), however this attractiveness is relative in nature and depends on many factors (Goetz 2006).

In the context of the bottom-up development, of particular importance is the level of innovation, which involves the need to create new resources, in place of the approach based on the optimal allocation of already existing resources. Factors affecting the level of innovation include the quality of the human capital and the social capital, therefore both local and regional network of business environment institutions play the important role here (Dorożyński, Urbaniak 2011, p. 191).

Local governments can actively take measures to support the intellectual capital of the region, e.g. by their participation in developing and supporting business incubators, technology centres, entrepreneurship promotion centres and science and technology parks (Poskrobko 2008, p. 104-106). Of great importance is also the activity, within the region, of research and development centres and universities conducting research, the results of which could find application in business operations.

Authorities of local government bodies have the ability to create the supply of investment offers for enterprises, among which - as in the example of the bioeconomy sector - one can identify elements pertaining to the operations of business environment institutions (Godlewska-Majkowska, Komor 2014, p. 56-60):

- political and administrative determinants, including the functioning of the institutional framework of the investment process, promotion of the region by BEIs, assistance in establishing contacts with the authorities of local government bodies,

- capital resources and synergy in financing of investments, including the number of financial institutions in the area,

- intellectual capital resources, including those pertaining to the business environment institu- uwage, że firmy nie działają w izolacji, ale są osadzone w konkretnych miejscach i kontekstach społeczno-ekonomicznych, które są ukształtowane także przez aktorów politycznych i instytucjonalnych (Tödtling, Asheim, Boschma 2013).

Instytucje otoczenia biznesu (IOB) mogą stanowić ważny element systemu pozyskiwania, przechowywania i dzielenia się wiedzą. Warto zauważyć, że regiony różnią się pod względem wyposażenia instytucjonalnego, co wpływa na innowacyjność i konkurencyjność przedsiębiorstw oraz sposoby i wydajność pozyskiwania przez nie wiedzy. W tym kontekście instytucje te stanowią ważny czynnik potencjalnej atrakcyjności inwestycyjnej regionu. Ponadto IOB odgrywają istotną rolę $\mathrm{w}$ stymulowaniu powstawania powiązań sieciowych, w tym klastrowych, pomiędzy partnerami w regionie. Przyczynia się to do wzrostu konkurencyjności podmiotów gospodarczych uczestniczących w tego typu strukturach, a także wpływa pozytywnie na poziom atrakcyjności miejsca dla potencjalnych inwestorów (Jankowiak 2014, s. 270). Należy podkreślić, że klastry stanowią atrakcyjne miejsce do lokowania inwestycji (w tym zagranicznych), przy czym atrakcyjność ta ma charakter względny i jest uzależniona od wielu czynników (Goetz 2006).

W kontekście koncepcji rozwoju oddolnego (bottom-up) ważne znaczenie ma poziom innowacyjności, który wiąże się z potrzebą kreacji nowych zasobów w miejsce podejścia opartego na optymalnej alokacji zasobów już istniejących. Do czynników wpływających na poziom innowacyjności należy zaliczyć jakość kapitału ludzkiego oraz kapitału społecznego, dlatego też istotną rolę odgrywa lokalna i regionalna sieć instytucji otoczenia biznesu (Dorożyński, Urbaniak 2011, s. 191).

Samorządy lokalne mogą w sposób aktywny podejmować działania wspierające kapitał intelektualny $\mathrm{w}$ regionie np. poprzez swój udział w tworzeniu i wspieraniu działalności inkubatorów przedsiębiorczości, centrów technologicznych, ośrodków promocji przedsiębiorczości czy parków naukowo-technologicznych (Poskrobko 2008, s. 104-106). Ważne znaczenie ma również działalność w regionie jednostek badawczo-rozwojowych oraz uczelni wyższych prowadzących badania naukowe, których wyniki mogłyby być aplikowane $\mathrm{w}$ działalności przedsiębiorstw.

Władze jednostek samorządowych mają możliwość kreowania podaży ofert inwestycyjnych dla przedsiębiorstw, wśród których - na przykładzie sektora biogospodarki - można wskazać elementy dotyczące działania instytucji otoczenia biznesu (Godlewska-Majkowska, Komor 2014, s. 56-60):

- uwarunkowania polityczno-administracyjne, $\mathrm{w}$ tym funkcjonowanie instytucjonalnych ram procesu inwestycyjnego, promocja regionu przez IOB, pomoc w nawiązywaniu kontaktów z władzami jednostek samorządu terytorialnego,

- zasoby kapitałowe i synergia w finansowaniu inwestycji, w tym wyposażenie obszaru w instytucje finansowe,

- zasoby kapitału intelektualnego, w tym dotyczące funkcjonujących $\mathrm{w}$ regionie instytucji okołobiznesowych, 
tions operating in the region,

- investment area resources, including the provision by the business-related institutions of information and advisory services regarding the regional portfolio of investment areas.

In the context of shaping the actual investment attractiveness of the region, promotion of both the country and the regions is of particular importance. Studies have shown that there is a positive correlation between the operations of sectors aimed at promoting investments and the attraction of foreign direct investments (FDI). The change of the approach from conducting marketing activities towards the organization of consulting services focused on the needs of investors is positively correlated with higher inflow of FDI (Exchange of Good Practice 2013 , p. 8). In addition, factors contributing to the effectiveness of promotional activities are, among others, consolidation of the institutional structure for promotion of investments, as well as the need for precise targeting of promotional initiatives (Active policies for attracting 2007, p. 88). Similarly to the need for the formulation and implementation of smart specializations on the regional level, it is necessary to implement the principle of smart orientation for entities that promote investments. This principle involves offering personalized values targeted to specific groups and sectors. It is worth noting that more and more often, in order to promote a country or a region investment-wise, the new media are also used, in order to maximize communication and reach a wider audience. Institutions can use the new online tools (e.g. social media). A website plays an important role in the assessment of the institution's online presence, as well as the effectiveness of its operations (Exchange of Good Practice 2013, p. 3-4).

The impact of business environment institutions on the region's investment attractiveness is discussed both in the Polish and foreign literature. It is worth noting that this impact is characterized by a diversity depending on multiple factors. One of them is the specific nature of the region. Research shows that the potential of business environment institutions is not sufficiently utilized for the development of entrepreneurship in rural areas in Poland (Bański 2015).

Another factor that differentiates the impact of BEIs on the investment attractiveness is the line of business. Austrian and Czech researchers compared the software companies in two regions with significant industrial traditions, differing in socioeconomic environment and the level of economic development. The authors are in position that exposes the important role of the regions' socio-economic and institutional environments in innovation processes. Important links pertaining to the sharing of knowledge between enterprises and other stakeholders (suppliers, customers, universities, institutions) are formed at different spatial levels - from local to global. Whereas, the regional level is of particular importance for innovation because the socio-economic and institutional structure of the regions can either greatly facilitate or hinder the
- zasoby terenów inwestycyjnych, w tym świadczenie przez instytucje otoczenia biznesu usług informacyjnych i doradczych na temat regionalnej oferty terenów inwestycyjnych.

W kontekście kształtowania rzeczywistej atrakcyjności inwestycyjnej regionu szczególne znaczenie ma promocja kraju i regionów. Badania wykazały, że istnieje pozytywna korelacja pomiędzy działalnością sektorów ukierunkowanych na promocję inwestycji i przyciąganiem bezpośrednich inwestycji zagranicznych (BIZ). Zmiana podejścia z prowadzenia działań marketingowych w kierunku organizacji usług doradztwa skoncentrowanego na potrzebach inwestorów jest dodatnio skorelowana z wyższym napły wem BIZ (Exchange of Good Practice 2013, s. 8). Ponadto czynnikami sprzyjającymi efektywności działań promocyjnych jest m.in. konsolidacja struktury instytucjonalnej dla promocji inwestycji, a także potrzeba precyzyjnego ukierunkowania inicjatyw promocyjnych (Active policies for attracting 2007, s. 88). Analogicznie do potrzeby formułowania i wdrażania inteligentnych specjalizacji na poziomie regionów należy wdrażać zasadę inteligentnego ukierunkowania dla podmiotów promujących inwestycje. Zasada ta polega na oferowaniu zindywidualizowanych wartości kierowanych do określonych grup i sektorów. Warto podkreślić, że coraz częściej w celu promocji inwestycyjnej kraju lub regionu wykorzystywane są również nowe media w celu zwielokrotnienia przekazu i dotarcia do szerszej grupy odbiorców. Instytucje mogą wykorzystywać nowe narzędzia internetowe (np. serwisy społecznościowe). Ważne znaczenie w ocenie obecności instytucji online, a także skuteczności jej działania ma strona internetowa (Exchange of Good Practice 2013, s. 3-4).

Wpływ instytucji otoczenia biznesu na atrakcyjność inwestycyjną regionu jest dyskutowany w literaturze krajowej i zagranicznej. Warto podkreślić, że wpływ ten charakteryzuje się zróżnicowaniem w zależności od wielu czynników. Jednym z nich jest specyfika regionu. Z badań wynika, że potencjał instytucji otoczenia biznesu nie jest dostatecznie wykorzystany do rozwoju przedsiębiorczości na terenach wiejskich w Polsce (Bański 2015).

Kolejnym czynnikiem różnicującym wpływ IOB na atrakcyjność inwestycyjną jest rodzaj działalności gospodarczej. Austriaccy i czescy naukowcy dokonali porównania producentów oprogramowania w dwóch regionach o znacznych tradycjach przemysłowych różniących się otoczeniem społeczno-gospodarczym oraz poziomem rozwoju gospodarczego. Autorzy prezentuja stanowisko eksponujace istotna rolę środowiska społeczno-gospodarczego i instytucjonalnego regionów w procesach innowacyjnych. Ważne powiązania dotyczące przepływu wiedzy pomiędzy przedsiębiorstwami i innymi podmiotami (dostawcami, klientami, uczelniami wyższymi, instytucjami) powstają na różnych poziomach przestrzennych - od lokalnego do globalnego. Przy czym poziom regionalny jest szczególnie istotny dla innowacji ponieważ struktura społeczno-gospodarcza i instytucjonalna regionów może znacznie ułatwić lub utrudnić proces innowacji i pozyskiwania wiedzy. W wyniku przepro- 
process of innovation and knowledge acquisition As a result of the conducted research it has been determined that in the case of ICT and software development companies, innovation and knowledge acquisition is more and more dependent on external factors related to the characteristics of the regional socio-economic and institutional environment and the quality of the Regional Innovation Systems (Tödtling, Skokan, Höglinger, Rumpel, Grillitsch 2013, p. 188-189).

Studies on the factors influencing the investment decisions of companies in the research and development sector have shown that the location of such entities depends on three main groups of factors, i.e.: the strategy of the parent company, dependent features of the potential and the factors related to the specificity of the host country. The main location factors in relation to the characteristics of the host country is the availability of the world-standard research infrastructure and the skilled workforce, as well as the dynamism of the national innovation system, understood as the degree of interaction and cooperation between different companies and institutions generating knowledge and sharing it (Guimón 2008, p. 3).

Another factor that differentiates the impact of BEIs on the investment attractiveness is the size of a project. M. Rosińska believes in a growing importance of the so-called soft factors, attracting investments while reducing the role of traditional stimulants of foreign investment (i.e. the hard factors). Among the soft factors the author lists the elements associated with the activities of BEIs, i.e. among others: the quality of administration that supports the economy and its ability to adapt to change, the costs of the regional promotion (co-participation in the integrated promotion system enabling the reduction of own costs), the image of the particular area as a place of conducting business (the existence of other entities, industrial districts, business centres, logistics hubs). Traditional factors often have the nature of neutral variables, i.e. elements neutral in nature, not having a significant impact on investment decisions (Rosińska 2007, p. 9). However, it should be noted that the soft locational factors are more important for micro and small investment projects. Factors of this type lose their importance especially in relation to large projects (Woźniak-Miszewska 2011, p. 371-372).

The difference in the institutional coverage of individual locations is an important factor in the decision-making process regarding internationalization of operations at the regional and national level. Therefore, just like the national level institutions stimulate the inflow of foreign direct investments into the countries, similarly the institutions at a lower taxonomic level are the investment location factor in the regions. Institutions are in fact one of the main factors determining how companies integrate with the local or regional economic system. It is worth noting that institutional factors are particularly important in transition economies (Zvirgzde, Schiller, Revilla Diez 2013). wadzonych badań stwierdzono, że w przypadku firm z sektora ICT i rozwoju oprogramowania, innowacyjność i pozyskiwanie wiedzy coraz bardziej zależy od zewnętrznych czynników związanych z cechami regionalnego środowiska społeczno-gospodarczego i instytucjonalnego oraz jakością Regionalnych Systemów Innowacji (Tödtling, Skokan, Höglinger, Rumpel, Grillitsch 2013, s. 188-189).

Badania dotyczące czynników wpływających na decyzje inwestycyjne przedsiębiorstw z branży badawczo-rozwojowej wykazały, że lokalizacja tego typu podmiotów jest uzależniona od trzech głównych grup czynników, tj.: strategii spółki dominującej, zależnych cech potencjału oraz czynników związanych ze specyfiką kraju przyjmującego. Głównymi czynnikami lokalizacji w odniesieniu do cech kraju goszczącego jest dostępność infrastruktury badawczej na światowym poziomie i wykwalifikowanej siły roboczej, a także dynamizm krajowego systemu innowacji, rozumiany jako stopień interakcji i współpracy między różnymi firmami i instytucjami tworzącymi wiedzę i dzielącymi się nią (Guimón 2008, s. 3).

Następnym czynnikiem różnicującym wpływ IOB na atrakcyjność inwestycyjną jest wielkość przedsięwzięcia. M. Rosińska jest zdania, że rośnie znaczenie tzw. czynników miękkich przyciągających inwestycje przy jednoczesnym zmniejszeniu roli tradycyjnych stymulant inwestycji zagranicznych (tzw. czynników twardych). Wśród czynników miękkich Autorka wymienia elementy związane z działalnością IOB, czyli m.in.: jakość administracji wspierającej gospodarkę i jej zdolność do dostosowywania się do zmian, koszty promocji regionalnej (współuczestnictwo w zintegrowanym systemie promocji pozwalające na obniżenie kosztów własnych), wizerunek danego obszaru jako miejsca prowadzenia działalności gospodarczej (istnienie innych podmiotów, okręgów przemysłowych, centrów biznesowych, węzłów logistycznych). Czynniki tradycyjne maja często charakter nominant, czyli elementów o charakterze neutralnym, nie mających istotnego wpływu na decyzje inwestycyjne (Rosińska 2007, s. 9). Należy jednak zwrócić uwagę, że miękkie czynniki lokalizacji mają większe znaczenie przy mikro- i małych projektach inwestycyjnych. Czynniki tego typu tracą na znaczeniu szczególnie w odniesieniu do dużych projektów (Woźniak-Miszewska 2011, s. 371-372).

Różnice w wyposażeniu instytucjonalnym poszczególnych lokalizacji są ważnym czynnikiem w procesie podejmowania decyzji dotyczącej internacjonalizacji działalności na poziomie regionalnym i krajowym. Tak więc, podobnie jak instytucje na poziomie krajowym stymulują napływ bezpośrednich inwestycji zagranicznych do krajów, podobnie instytucje na niższym szczeblu taksonomicznym są czynnikiem lokalizacji inwestycji w regionach. Instytucje stanowią bowiem jeden z głównych czynników determinujących sposób zintegrowania firmy z lokalnym lub regionalnym systemem gospodarczym. Warto podkreślić, że czynniki instytucjonalne są szczególnie istotne $\mathrm{w}$ gospodarkach $\mathrm{w}$ okresie przejściowym (Zvirgzde, Schiller, Revilla Diez 2013). 
Decisions of enterprises in regard to the internationalization of their operations are the subject of discussion under the eclectic theory of JH Dunning (OLI). This decision is determined by three groups of factors, i.e.: 0 - ownership-specific advantages, L - location-specific advantages and I - internalization-specific advantages (Dunning 2002, p. 104). Business environment institutions can play an important role in relation to each group of those factors. The institutions' activities in regard to supporting ownership-specific advantages may relate to, among others, the assistance in increasing the company's innovation potential (e.g. by facilitating contacts and the transfer of knowledge), the access to information resources, the ability to enter beneficial cooperative relations. Location-specific advantages are mainly associated with the level of the locational attractiveness of the country or region, that is influenced by many factors, including the soft and hard infrastructure. In relation to the internalizationspecific advantages, the activity of BEIs is conducive to reducing uncertainty and lowering transaction costs.

\section{The institutional support of the investor and the entrepreneur in Poland - the regional approach}

Pursuant to the Regulation of the Minister of Regional Development a business environment institution is "a micro-entrepreneur, small or mediumsized entrepreneur, and an entrepreneur other than micro, small or medium-sized entrepreneur, regardless of its legal form, which does not operate for profit, or one that allocates profit for statutory purposes, and which conducts an activity that contributes to creation of favourable conditions for the development of entrepreneurship" (Regulation of the Minister of Regional development 2009). Among the business environment institutions in the province (with the exception of scientific and research institutions) that have an impact on the economic development of the region are, among others, chambers of commerce, associations, business incubators (business and technology related), parks (technology, science and research, industrial, investment parks), technology transfer centres, counselling centres, financial institutions and, development agencies, Regional Investor Service Centres.

The total of 154 business environment institutions operating in all of the provinces (Table 1) have been covered in this article.

The choice of the research method was expedient and included the most active entities operating in individualprovinces. Identification of suchinstitutions was performed with the participation of experts from the Department of Regional Development of the Polish Information and Foreign Investment Agency. The research included an assessment of the content posted on the websites of selected institutions that provide support for entrepreneurs in the regions. The
Decyzje przedsiębiorstw w zakresie internacjonalizacji działalności stanowią przedmiot rozważań w ramach eklektycznej teorii J.H. Dunninga (OLI). Decyzja ta jest uwarunkowana trzema grupami czynników, tj.: specyficznymi przewagami własnościowymi (O - ownership-specific advantages), specyficznymi przewagami lokalizacyjnymi (L location-specific advantages) oraz specyficznymi przewagami internalizacji (I - internalization-specific advantages) (Dunning 2002, s. 104). Instytucje otoczenia biznesu mogą odgrywać istotną rolę w odniesieniu do każdej grupy czynników. Działalność instytucji w zakresie wspierania specyficznych przewag własnościowych może dotyczyć m.in. pomocy w zakresie zwiększenia potencjału innowacyjnego przedsiębiorstwa (np. poprzez ułatwianie kontaktów i przepływu wiedzy), dostępu do zasobów informacyjnych, możliwości nawiązywania korzystnych relacji kooperacyjnych. Specyficzne przewagi lokalizacyjne są związane głównie z poziomem atrakcyjności lokalizacyjnej kraju lub regionu, na który wpływa wiele czynników, w tym m.in. infrastruktura miękka i twarda. W odniesieniu do specyficznych przewag internalizacji działalność IOB sprzyja obniżeniu poziomu niepewności oraz obniżeniu kosztów transakcyjnych.

\section{Wsparcie instytucjonalne inwestora i przedsiębiorcy w Polsce - ujęcie regionalne}

Zgodnie z Rozporządzeniem Ministra Rozwoju Regionalnego przez instytucje otoczenia biznesu należy rozumieć „mikroprzedsiębiorcę, małego lub średniego przedsiębiorce, a także przedsiębiorce innego niż mikroprzedsiębiorca, mały lub średni przedsiębiorca, bez względu na formę prawna, który nie działa dla zysku lub przeznacza zysk na cele statutowe i prowadzi działalność służąca tworzeniu korzystnych warunków dla rozwoju przedsiębiorczości" (Rozporządzenie Ministra Rozwoju Regionalnego 2009). Wśród instytucji okołobiznesowych w województwie (z wyłączeniem instytucji naukowo-badawczych), które mają wpływ na rozwój gospodarczy regionu znajdują się m.in. izby gospodarcze, stowarzyszenia, inkubatory (przedsiębiorczości i technologiczne), parki (technologiczne, naukowo-badawcze, przemysłowe, inwestycyjne), centra transferu technologii, ośrodki doradztwa, instytucje finansowe, agencje rozwoju oraz Regionalne Centra Obsługi Inwestora.

W niniejszym artykule badaniami objęto łącznie 154 instytucje okołobiznesowe działające na terenie wszystkich województw (tab. 1.).

Dobór próby badawczej miał charakter celowy i obejmował najbardziej aktywne podmioty funkcjonujące $w$ poszczególnych województwach. Identyfikacji tego typu instytucji dokonano przy współudziale ekspertów z Departamentu Rozwoju Regionalnego Polskiej Agencji Informacji i Inwestycji Zagranicznych. Badanie obejmowało ocenę treści zamieszczonych na stronach internetowych wybranych instytucji świadczących wsparcie dla inwestora i przedsiębiorcy $w$ regionach. Przedmiotem badań jakościowych była identyfikacja i ocena zakresu 
Table 1. Business environment institutions surveyed in 2015 in Poland by province

Tabela 1. Instytucje otoczenia biznesu objęte badaniem w 2015 r. w Polsce według województw

\begin{tabular}{|c|c|c|c|c|c|c|c|}
\hline $\begin{array}{c}\text { Province/ } \\
\text { Województwo }\end{array}$ & $\begin{array}{l}\text { Regional } \\
\text { Investor } \\
\text { Service } \\
\text { Centres/ } \\
\text { Regional- } \\
\text { ne Centra } \\
\text { Obsługi } \\
\text { Inwestora }\end{array}$ & $\begin{array}{l}\text { Chambers } \\
\text { of Commer- } \\
\text { ce/ } \\
\text { Izby gospo- } \\
\text { darcze }\end{array}$ & \begin{tabular}{|c|} 
Asso- \\
ciations \\
(including \\
business \\
centres)/ \\
Stowa- \\
rzyszenia \\
(w tym cen- \\
tra biznesu) \\
\end{tabular} & $\begin{array}{l}\text { Incubators/ } \\
\text { Inkubatory }\end{array}$ & $\begin{array}{c}\text { Parks/ } \\
\text { Parki }\end{array}$ & $\begin{array}{l}\text { Other/ } \\
\text { Inne }\end{array}$ & $\begin{array}{l}\text { TOTAL/ } \\
\text { SUMA }\end{array}$ \\
\hline Dolnośląskie & 1 & 2 & 1 & 2 & 3 & 0 & 9 \\
\hline Kujawsko-Pomorskie & 1 & 2 & 1 & 0 & 2 & 0 & 6 \\
\hline Lubelskie & 1 & 2 & 1 & 2 & 2 & 1 & 9 \\
\hline Lubuskie & 1 & 0 & 1 & 1 & 4 & 3 & 10 \\
\hline Łódzkie & 1 & 2 & 1 & 2 & 2 & 0 & 8 \\
\hline Małopolskie & 1 & 3 & 1 & 1 & 1 & 3 & 10 \\
\hline Mazowieckie & 1 & 3 & 0 & 1 & 1 & 0 & 6 \\
\hline Opolskie & 1 & 2 & 1 & 1 & 3 & 3 & 11 \\
\hline Podkarpackie & 1 & 1 & 1 & 5 & 3 & 4 & 15 \\
\hline Podlaskie & 1 & 1 & 1 & 2 & 2 & 3 & 10 \\
\hline Pomorskie & 1 & 1 & 1 & 1 & 2 & 2 & 8 \\
\hline Śląskie & 1 & 3 & 1 & 1 & 3 & 2 & 11 \\
\hline Świętokrzyskie & 1 & 1 & 0 & 1 & 1 & 2 & 6 \\
\hline Warmiński-Mazurskie & 1 & 1 & 0 & 4 & 3 & 1 & 10 \\
\hline Wielkopolskie & 1 & 4 & 0 & 2 & 2 & 2 & 11 \\
\hline Zachodniopomorskie & 1 & 3 & 0 & 2 & 6 & 2 & 14 \\
\hline TOTAL/ ŁĄCZNIE & 16 & 31 & 11 & 28 & 40 & 28 & 154 \\
\hline
\end{tabular}

Source: own elaboration.

Źródło: opracowanie własne na podstawie przeprowadzonych badań.

subject of the qualitative research was identification and assessment of the extent of the support offered to entrepreneurs by business environment institutions.

Among the group of the surveyed institutions the most numerous were Parks (technology, science \& research, industrial, investment parks) - a total of 40 entities, and Chambers of Commerce - 31. The analysis has covered 28 Incubators (technological and entrepreneurial), 16 Regional Investor Service Centres (RCOI) and 11 associations (Table 1). Among the other surveyed bodies one can distinguish, among others, technology transfer centres, counselling centres, financial institutions, development agencies.

The biggest number of business environment institutions have been analyzed in the Podkarpackie province (15 entities), Zachodniopomorskie (14 entities), and Śląskie, Opolskie and Wielkopolskie provinces (11 institutions, respectively). As a result of the conducted research it can be concluded that the offer presented on the websites of business environment institutions was not characterized by regional diversity. Thus, a general conclusion can be put forward that in all provinces the surveyed entities recognized the importance of a website as a tool in contact with partners.

Business environment institutions offered various types of services, including information, advisory and training services in the field of: commencement, performance and cancellation of business, obtaining support for projects from external funds, entering wsparcia oferowanego przedsiebbiorcom i inwestorom przez instytucje otoczenia biznesu.

W grupie badanych instytucji najliczniej reprezentowane były Parki (technologiczne, naukowo-badawcze, przemysłowe, inwestycyjne) - łącznie 40 podmiotów oraz Izby gospodarcze - 31. Analizie poddano 28 Inkubatorów (technologicznych oraz przedsiębiorczości), 16 Regionalnych Centrów Obsługi Inwestora (RCOI) oraz 11 stowarzyszeń (tab. 1.). Wśród innych badanych jednostek wyróżnić można m.in. centra transferu technologii, ośrodki doradztwa, instytucje finansowe, agencje rozwoju.

Najwięcej instytucji otoczenia biznesu poddano analizie $\mathrm{w}$ regionie podkarpackim (15 podmiotów), zachodniopomorskim (14 jednostek) oraz śląskim, opolskim i wielkopolskim (po 11 instytucji). W wyniku przeprowadzonych badań można stwierdzić, że oferta prezentowana na stronach internetowych instytucji okołobiznesowych nie cechuje się zróżnicowaniem regionalnym. Można więc wskazać generalny wniosek, że we wszystkich województwach badane podmioty dostrzegają znaczenie strony internetowej jako narzędzia kontaktu z partnerami.

Instytucje otoczenia biznesu oferują różnego rodzaju usługi, w tym m.in. usługi informacyjne, doradcze i szkoleniowe w zakresie: podejmowania, wykonywania oraz rezygnacji z prowadzenia działalności gospodarczej, możliwości uzyskania wsparcia na realizację projektów ze środków zewnętrznych, wchodzenia na rynki zagraniczne i rozwoju 
foreign markets and export development. The portfolio of pro-innovation services included, among others, technology audits, technology transfer and services related to the commercialization of results of scientific research. For entrepreneurs, of particular significance were the services related to matching of business partners, as well as the financial services (offered e.g. by Loan funds operating within the structures of the surveyed institutions). Among the services dedicated to both national and foreign investors one can list, among others: organization of trade missions connected with the promotion of the region and indigenous businesses, maintaining a database of investment areas and facilities, advising on the choice of a proper place for investments and a legal form of business, assisting in registration of a company, organizing meetings with representatives of local governments, landowners and experts in various fields (e.g. law, taxes, recruitment), and also post-investment services.

The services offered by the business environment institutions significantly facilitate the acquisition, storage and sharing of knowledge thereby stimulating the growth of innovation and competitiveness of enterprises. This contributes to the development of potential investment attractiveness of the location. At the same time, the actions taken by BEIs aimed at promoting both individual regions and the entire country, have a positive impact on the development of the actual investment attractiveness.

The research has shown that among the institutions being analyzed the offer of Parks can be considered as the most comprehensive in regard to the support of entrepreneurs. It usually included the provision of premises necessary to commence and conduct a business activity based, in particular, on modern technologies; as well as the provision of investment areas, as well as the training, advising, information and pro-innovation services. This may be an important impetus for business entities in regard to their locationrelated decisions. Preferential conditions regarding the lease of property or the provision of services, which reduce the cost of starting and running a business, increase the investment attractiveness, especially for micro-, small and medium enterprises, which often operate in conditions of limited possibilities of obtaining financing.

One can observe a tendency to create in the Parks: - Research laboratories ${ }^{1}$

${ }^{1}$ Park Naukowo-Technologiczny Uniwersytetu Zielonogórskiego w Nowym Kisielinie [Science and Technology Park of the University of Zielona Góra in Nowy Kisielin] http://www.pnt. uz.zgora.pl, Park Technologiczny INTERIOR w Nowej Soli [INTERIOR Technology Park in Nowa Sól]http://www.interiorns pl/, Łódzki Regionalny Park Naukowo-Technologiczny Sp. z o.o. [Regional Science and Technology Park in Łódź]http://www. technopark.lodz.pl/, Park Naukowo - Technologiczny Polska Wschód w Suwałkach Sp. z o.o. [Poland-East Science and Technology Park in Suwałki]www.park.suwalki.pl, Białostocki Park Naukowo - Technologiczny [Science and Technology Park in Białystok]www.bpnt.bialystok.pl, Poznański Park NaukowoTechnologiczny Fundacji Uniwersytetu im. Adama Mickiewicza [Science and Technology Park of the Adam Mickiewicz Foundation in Poznań]www.ppnt.poznan.pl, Park Naukowo-Technologiczny w Ełku [Science and Technology Park in Ełk] http://www. technopark.elk.pl/, Gdański Park Naukowo-Technologiczny [Science and Technology Park in Gdańsk]www.gpnt.pl, [accessed: 15.12.2015] eksportu. Oferta usług proinnowacyjnych obejmuje m.in. audyty technologiczne, transfer technologii czy usługi związane z komercjalizacja wyników badań naukowych. Dla przedsiębiorców istotną rolę odgrywają usługi związane z kojarzeniem partnerów biznesowych, a także usługi finansowe (oferowane np. przez Fundusze pożyczkowe działające w strukturach badanych instytucji). Wśród usług dedykowanych inwestorom krajowym i zagranicznym wymienić można m.in.: organizację misji gospodarczych połączonych z promocją regionu i rodzimych przedsiębiorstw, prowadzenie bazy danych o terenach i obiektach inwestycyjnych, doradztwo w zakresie wyboru właściwego miejsca pod inwestycje oraz formy prawnej prowadzenia działalności gospodarczej, pomoc w rejestracji firmy, organizację spotkań z przedstawicielami samorządów, właścicielami terenów oraz ekspertami w różnych dziedzinach (np. prawo, podatki, rekrutacja), a także usługi poinwestycyjne.

Usługi oferowane przez instytucje otoczenia biznesu w istotny sposób ułatwiaja pozyskiwanie, przechowywanie i dzielenie się wiedzą stymulując tym samym wzrost innowacyjności i konkurencyjności przedsiębiorstw. Przyczynia się to do kształtowania potencjalnej atrakcyjności inwestycyjnej miejsca. Jednocześnie działania podejmowane przez IOB mające na celu promocję poszczególnych regionów, a także całego kraju, wpływają pozytywnie na kształtowanie rzeczywistej atrakcyjności inwestycyjnej.

W toku badań stwierdzono, że wśród analizowanych instytucji ofertę Parków można uznać za najbardziej kompleksową w zakresie wsparcia przedsiębiorców. Obejmuje ona z reguły udostępnienie bazy lokalowej, niezbędnej dla podejmowania i prowadzenia działalności gospodarczej opartej w szczególności na nowoczesnych technologiach, tereny inwestycyjne, usługi szkoleniowe, doradcze, informacyjne, proinnowacyjne. Może to stanowić ważny impuls do podjęcia decyzji lokalizacyjnej dla podmiotów gospodarczych. Preferencyjne warunki oferty wynajmu powierzchni czy świadczenia usług, skutkujace obniżeniem kosztów rozpoczęcia i prowadzenia działalności gospodarczej, wpływają na wzrost atrakcyjności inwestycyjnej szczególnie dla przedsiębiorstw mikro-, małych i średnich, które działają często w warunkach ograniczonych możliwości pozyskania źródeł finansowania.

Można zaobserwować tendencję do tworzenia w ramach Parków:

- laboratoriów badawczych ${ }^{1}$,

\footnotetext{
Park Naukowo-Technologiczny Uniwersytetu Zielonogórskiego w Nowym Kisielinie http://www.pnt.uz.zgora.pl, Park Technologiczny INTERIOR w Nowej Soli http://www.interiorns.pl/, Łódzki Regionalny Park Naukowo-Technologiczny Sp. z o.o. http:// www.technopark.lodz.pl/, Park Naukowo - Technologiczny Polska - Wschód w Suwałkach Sp. z o.o. www.park.suwalki.pl, Białostocki Park Naukowo - Technologiczny www.bpnt.bialystok pl, Poznański Park Naukowo-Technologiczny Fundacji Uniwersytetu im. Adama Mickiewicza www.ppnt.poznan.pl, Park Naukowo-Technologiczny w Ełku http://www.technopark.elk.pl/, Gdański Park Naukowo-Technologiczny www.gpnt.pl, (dostęp: 15.12.2015).
} 


\section{- Business Incubators and Technology Incuba- tors ${ }^{2}$, \\ - Data centres. ${ }^{3}$}

In the course of the research a tendency was observed to include the Park areas into Special Economic Zones ${ }^{4}$, which is a factor stimulating the inflow of investments. Parks were also involved in the formation of cluster structures ${ }^{5}$, which creates favourable conditions for cooperation between enterprises, business environment institutions and scientific entities, and also stimulates the growth of innovation of the entities involved in this type of structures.

For investors, a particularly important form of support is the system of Regional Investor Service

${ }^{2}$ Podkarpacki Park Naukowo-Technologiczny AEROPOLIS [Podkarpackie Science and Technology Park AEROPOLIS] www.aeropolis.com.pl, Olsztyński Park Naukowo-Technologiczny [Science and Technology Park in Olsztyn]http://opnt.olsztyn.pl/, Poznański Park Technologiczno - Przemysłowy [Technology and Industry Park in Poznań]www.pptp.pl, Puławski Park Naukowo-Technologiczny [Science and Technology Park in Puławy]www.ppnt. pulawy.pl, Łódzki Regionalny Park Naukowo-Technologiczny Sp. z o.o. [Regional Science and Technology Park in Łódź]http://www. technopark.lodz.pl/, Bełchatowsko Kleszczowski Park Przemysłowo Technologiczny Sp. z o.o. [Bełchatów-Kleszczów Industry and Technology Park]http://www.ppt.belchatow.pl/, Park Naukowo - Technologiczny Polska - Wschód w Suwałkach Sp. z o.o. [Poland-East Science and Technology Park in Suwałki]www.park suwalki.pl, Białostocki Park Naukowo - Technologiczny [Science and Technology Park in Białystok]www.bpnt.bialystok.pl, Park Naukowo-Technologiczny Uniwersytetu Zielonogórskiego w Nowym Kisielinie [Science and Technology Park of the University of Zielona Góra in Nowy Kisielin]www.pnt.uz.zgora.pl, Poznański Park Naukowo-Technologiczny Fundacji Uniwersytetu im. Adama Mickiewicza [Science and Technology Park of the Adam Mickiewicz Foundation in Poznań]www.ppnt.poznan.pl, Białogardzki Park Inwestycyjny „Invest-Park” Sp. z o.o. ["Invest-Park” Investment Park in Białogard]http://www.investpoland.info, Park Naukowo-Technologiczny w Ełku [Science and Technology Park in Ełk]http://www.technopark.elk.pl/, Kielecki Park Technologiczny [Technology Park in Kielce]http://www.technopark.kielce.pl/, Krakowski Park Technologiczny Sp. z o.o. [Technology Park in Kraków]www.sse.krakow.pl, Tarnobrzeski Park Przemysłowo-Technologiczny [Industry and Technology Park in Tarnobrzeg] www.tppt.tarnobrzeg.pl, Gdański Park Naukowo-Technologiczny [Science and Technology Park in Gdańsk] www.gpnt.pl, Dolnośląski Park Innowacji i Nauki [Dolnośląskie Innovation and Science Park]www.dpin.pl, [accessed: 15.12.2015].

${ }^{3}$ See: Data Centre in Toruński Park Technologiczny [Technology Park in Toruń] www.technopark.org.pl, Park Technologiczny INTERIOR w Nowej Soli [INTERIOR Technology Park in Nowa Sól]http://www.interiorns.pl/, Gdański Park Naukowo-Technologiczny [Science and Technology Park in Gdańsk] www.gpnt.pl, [accessed: 15.12.2015].

${ }^{4}$ Bydgoski Park Przemysłowo-Technologiczny [Industry and Technology Park in Bydgoszcz]www.bppt.pl, Legnicki Park Technologiczny LETIA S.A. [LETIA Technology Park in Legnica]www.letia.pl, Kędzierzyńsko - Kozielski Park Przemysłowy [Industrial Park in Kędzierzyn-Koźle]www.kkpp.pl, Goleniowski Park Przemysłowy [Industrial Park in Goleniów] http://go leniow.biz/, Białogardzki Park Inwestycyjny "Invest-Park” Sp. z o.o. ["Invest-Park" Investment Park in Białogard]http://www. investpoland.info, Park Naukowo-Technologiczny w Ełku [Science and Technology Park in Ełk] http://www.technopark.elk.pl/, Kielecki Park Technologiczny [Technology Park in Kielce]http:// www.technopark.kielce.pl/, Krakowski Park Technologiczny Sp. z o.o. [Technology Park in Kraków]www.sse.krakow.pl, Tarnobrzeski Park Przemysłowo-Technologiczny [Industry and Technology Park in Tarnobrzeg] www.tppt.tarnobrzeg.pl, Gdański Park Naukowo-Technologiczny [Science and Technology Park in Gdańsk]www.gpnt.pl, [accessed: 15.12.2015].

${ }^{5}$ For example, the coordinator of the "Szkody Górnicze" [Mining Damage] Construction Cluster is the Śląskie Industry and Technology Park in Ruda Śląska - http://sppt.pl/, [accessed: 15.12.2015].; Klaster Innowacyjnych Technologii w Wytwarzaniu CINNOMATECH [Cluster of Innovative Manufacturing Technologies] operates on the territory of Dolnośląski Park Innowacji i Nauki [Dolnośląskie Innovation and Science Park] - www.dpin pl, [accessed: 15.12.2015]
- Inkubatorów Przedsiębiorczości oraz Inkubatorów Technologicznych ${ }^{2}$,

- Centrów przetwarzania danych (Data Center) ${ }^{3}$.

W toku badań zaobserwowano także tendencję włączania terenów Parku do Specjalnej Strefy Ekonomicznej ${ }^{4}$, co jest czynnikiem stymulującym napływ inwestycji. Parki angażują się również w tworzenie struktur klastrowych ${ }^{5}$, co stwarza korzystne warunki do współpracy pomiędzy przedsiębiorstwami, instytucjami otoczenia biznesu i jednostkami naukowymi, a także stymuluje wzrost innowacyjności podmiotów uczestniczących w tego typu strukturach.

Dla inwestorów szczególnie ważnym wsparciem jest system Regionalnych Centrów Obsługi Inwestora (RCOI) stworzony przez Polską Agencję Informacji i Inwestycji Zagranicznych S.A. (PAIiIZ) w porozumieniu $\mathrm{z}$ marszałkami województw dla zapewnienia inwestorom kompleksowej obsługi na poziomie każdego województwa. RCOI działają według standardów określonych przez PAIiIZ stanowiąc źródło potrzebnych inwestorowi informacji dotyczących gospodarki regionu, przepisów i aktów prawnych, ofert inwestycyjnych oraz aktualnych danych o gospodarce regionu. ${ }^{6} \mathrm{~W}$ tym kontekście działalność RCOI przyczynia się do kształtowania potencjalnej atrakcyjności inwestycyjnej. Warto zauważyć, że misją PAIiIZ jest również kreowanie pozytywnego wizerunku Polski w świecie oraz promo-

\footnotetext{
${ }^{2}$ Podkarpacki Park Naukowo-Technologiczny AEROPOLIS www. aeropolis.com.pl, Olsztyński Park Naukowo-Technologiczny http://opnt.olsztyn.pl/, Poznański Park Technologiczno - Przemysłowy www.pptp.pl, Puławski Park Naukowo-Technologiczny www.ppnt.pulawy.pl, Łódzki Regionalny Park Naukowo-Technologiczny Sp. z o.o. http://www.technopark.lodz.pl/, Bełchatowsko Kleszczowski Park Przemysłowo Technologiczny Sp. z o.o. http://www.ppt.belchatow.pl/, Park Naukowo - Technologiczny Polska - Wschód w Suwałkach Sp. z o.o. www.park.suwalki.pl, Białostocki Park Naukowo - Technologiczny www.bpnt.bialystok.pl, Park Naukowo-Technologiczny Uniwersytetu Zielonogórskiego w Nowym Kisielinie www.pnt.uz.zgora.pl, Poznański Park Naukowo-Technologiczny Fundacji Uniwersytetu im. Adama Mickiewicza www.ppnt.poznan.pl, Białogardzki Park Inwestycyjny „Invest-Park” Sp. z o.o. http://www.investpoland.info, Park Naukowo-Technologiczny w Ełku http://www.technopark. elk.pl/, Kielecki Park Technologiczny http://www.technopark. kielce.pl/, Krakowski Park Technologiczny Sp. z o.o. www.sse. krakow.pl, Tarnobrzeski Park Przemysłowo-Technologiczny www.tppt.tarnobrzeg.pl, Gdański Park Naukowo-Technologiczny www.gpnt.pl, Dolnośląski Park Innowacji i Nauki www.dpin.
} pl, (dostęp: 15.12.2015).

${ }^{3}$ Zob.: Data Center w Toruńskim Parku Technologicznym www. technopark.org.pl, Parku Technologicznym INTERIOR w Nowej Soli http://www.interiorns.pl/, Gdańskim Parku Naukowo-Technologicznym www.gpnt.pl, (dostep: 15.12.2015).

${ }^{4}$ Bydgoski Park Przemysłowo-Technologiczny www.bppt.pl, Legnicki Park Technologiczny LETIA S.A. www.letia.pl, Kedzierzyńsko - Kozielski Park Przemysłowy www.kkpp.pl, Goleniowski Park Przemysłowy http://goleniow.biz/, Białogardzki Park Inwestycyjny „Invest-Park” Sp. z o.o. http://www.investpoland. info, Park Naukowo-Technologiczny w Ełku http://www.technopark.elk.pl/, Kielecki Park Technologiczny http://www.technopark.kielce.pl/, Krakowski Park Technologiczny Sp. z o.o. www. sse.krakow.pl, Tarnobrzeski Park Przemysłowo-Technologiczny www.tppt.tarnobrzeg.pl, Gdański Park Naukowo-Technologiczny www.gpnt.pl, (dostęp: 15.12.2015).

${ }^{5}$ Na przykład koordynatorem Klastra Budowlanego „Szkody Górnicze” jest Śląski Park Przemysłowo-Technologiczny w Rudzie Śląskiej - http://sppt.pl/, (dostęp: 15.12.2015).; Klastrer Innowacyjnych Technologii w Wytwarzaniu CINNOMATECH działa na trenie Dolnoślaskiego Parku Innowacji i Nauki - www.dpin.pl, (dostęp: 15.12.2015).

${ }^{6}$ Polska Agencja Informacji i Inwestycji Zagranicznych http:// www.paiz.gov.pl/regiony/coi, (dostęp: 04.04.2016). 
Centres (RCOI) created by the Polish Agency for Information and Foreign Investment (PAIilZ in consultation with the province marshals in order to provide investors with comprehensive support at the level of each province. RCOIs operate according to the standards set by PAIiIZ, providing investors with necessary information about the region's economy, laws and regulations, and investment opportunities. ${ }^{6}$ In this context, RCOIs' activities contribute to the development of potential investment attractiveness. It should be noted that PAIiIZ's mission is also to create a positive image of Poland in the world and to promote Polish products and services, which is an element contributing to the increase in the actual investment attractiveness.

Regional Investor Service Centres operate in all provinces in Poland.7They work in the "one stop shop" model that allows investors to obtain comprehensive service at every stage of the investment process.

${ }^{6}$ Polska Agencja Informacji i Inwestycji Zagranicznych [Polish Information and Foreign Investment Agency]http://www.paiz. gov.pl/regiony/coi, [accessed: 04.04.2016].

Urząd Marszałkowski Województwa Lubelskiego w Lublinie [Marshal's Office of the Lubelskie Province in Lublin], Departament Gospodarki i Współpracy Zagranicznej [Department of Economy and International Cooperation] http://www.invest. lubelskie.pl/pl, Rzeszowska Agencja Rozwoju Regionalnego S.A [Rzeszów Regional Development Agency], Centrum Obsługi Inwestora [Investor Service Centre] http://www.coi.rzeszow.pl, Urząd Marszałkowski Województwa Podlaskiego [Marshal's Office of the Podlaskie Province], Centrum Obsługi Inwestora [Investor Service Centre] / Centrum Obsługi Inwestorów i Eksporterów [Service Centre for Investors and Exporters] http:// coi.wrotapodlasia.pl, Urząd Miasta Kielce [Kielce City Office], Wydział Rozwoju i Rewitalizacji Miasta [Department of Development and Revitalization of the City], Centrum Obsługi Inwestora [Investor Service Centre], http://www.invest.kielce.pl, Centrum Business in Małopolska [Business in Małopolska Centre], http:// businessinmalopolska.pl, Urząd Marszałkowski Województwa Śląskiego [Marshal's Office of the Śląskie Province], Wydział Gospodarki, Turystyki i Sportu [Department of Economy, Tourism and Sport], Slaskie Centrum Obsługi Inwestora i Eksportera [The Ślaskie Province's Service Centre for Investors and Exporters] http://www.invest-in-silesia.pl, Opolskie Centrum Rozwoju Gospodarki [The Opolskie Province's Centre for Economic Development], Centrum Obsługi Inwestora i Eksportera [Investor and Exporter Service Centre] http://coi.opolskie.pl, Dolnośląska Agencja Współpracy Gospodarczej Sp. z. o. o. [Lower Silesian Agency of Economic Cooperation], Dolnośląskie Centrum Obsługi Inwestora i Eksportera DAWG [Lower Silesian Centre for Investor and Exporter Service DAWG] http://dawg.pl/, Urzad Marszałkowski Województwa Lubuskiego [Marshal's Office of the Lubuskie Province], Departament Przedsiębiorczości i Strategii Marki [Department of Enterprise and Brand Strategy], Centrum Obsługi Inwestora [Investor Service Centre] http://www.coi-lubuskie.pl, Urząd Marszałkowski Województwa Zachodniopomorskiego [Marshal's Office of the Zachodniopomorskie Province], Centrum Obsługi Inwestorów i Eksporterów [Service Centre for Investors and Exporters] www.coi.wzp.pl/, Invest in Pomerania http://www. investinpomerania.pl, Warmińsko-Mazurska Agencja Rozwoju Regionalnego S. A. w Olsztynie [Warmia and Mazury Regional Development Agency in Olsztyn], Warmińsko-Mazurskie Centrum Obsługi Inwestora [the Warmia and Mazury Investor Service Centre] http://www.investinwarmiaandmazury.com, Urząd Marszałkowski Województwa Kujawsko-Pomorskiego [Marshal's Office of the Kujawsko-Pomorskie Province], Kujawsko-Pomorskie Centrum Obsługi Inwestora [Investor Service Centre of the Kujawsko-Pomorskie Province] www.coi.kujawsko-pomorskie. pl, Stowarzyszenie Gmin i Powiatów Wielkopolski [Association of Wielkopolska Municipalities and Counties], Centrum Obsług Inwestora [Investor Service Centre] www.investinwielkopolska. pl/, Urząd Marszałkowski Województwa Łódzkiego [Marshal's Office of the Łódzkie Province], Departament ds. Przedsiębiorczości [Department of Enterprise], Wydział - Regionalne Centrum Obsługi Inwestora i Eksportera [Division - Regional Centre for Investor and Exporter Service] http://www.investin.lodzkie.pl, Agencja Rozwoju Mazowsza S.A. [Mazovia Development Agency] Centrum Obsługi Inwestora i Eksportera [Centre for Investor and Exporter Service] coie.armsa.pl/, [accessed: 20.12.2015] cja polskich produktów i usług, co stanowi element przyczyniający się do wzrostu rzeczywistej atrakcyjności inwestycyjnej.

Regionalne Centra Obsługi Inwestora funkcjonują na terenie wszystkich województw w Polsce. ${ }^{7}$ Działają one w standardzie „one stop shop”, umożliwiającym inwestorom otrzymanie kompleksowej obsługi na każdym etapie procesu inwestycyjnego. Zidentyfikowano występowanie zróżnicowania nazw poszczególnych RCOI, a także brak ujednolicenia ich stron internetowych oraz ofert na nich zamieszczonych. Zaobserwowana została dowolność w kształtowaniu stron internetowych RCOI, zarówno w odniesieniu do treści na nich zamieszczanych, jak i ich szaty graficznej.

W wyniku przeprowadzonych badań stwierdzono, że strony internetowe analizowanych instytucji stanowią źródło potrzebnych inwestorowi informacji regionalnych, przepisów i aktów prawnych, ofert inwestycyjnych, aktualnych danych o gospodarce regionu, a także zachęt i ulg inwestycyjnych. Oferta części badanych instytucji obejmuje również przyjmowanie i obsługę misji gospodarczych przyjazdowych i wyjazdowych, a także pomoc inwestorom w kontaktach $\mathrm{z}$ administracją lokalną, instytucjami otoczenia biznesu i partnerami gospodarczymi. $\mathrm{Na}$ stronach internetowych niektórych RCOI można również zapoznać się z przewodnikami dla inwestora, zawierającymi m.in. informacje dotyczące zakładania oraz form prowadzenia działalności gospodarczej w Polsce, uzyskania potrzebnych koncesji i zezwoleń, prawa pracy, podatków, itp. Część stron internetowych zawiera również informacje o funkcjonujących w województwie instytucjach wspierajacych inwestorów, w tym o instytucjach parkowych. Istotne znaczenie ma fakt zamieszczenia na stronach internetowych wszystkich RCOI baz/wyszukiwarek ofert inwestycyjnych, co stanowi duże ułatwienie dla

7 Urząd Marszałkowski Województwa Lubelskiego w Lublinie, Departament Gospodarki i Współpracy Zagranicznej http://www. invest.lubelskie.pl/pl, Rzeszowska Agencja Rozwoju Regionalnego S.A., Centrum Obsługi Inwestora http://www.coi.rzeszow pl, Urzad Marszałkowski Województwa Podlaskiego, Centrum Obsługi Inwestora /Centrum Obsługi Inwestorów i Eksporterów http://coi.wrotapodlasia.pl, Urząd Miasta Kielce, Wydział Rozwoju i Rewitalizacji Miasta, Centrum Obsługi Inwestora, http:// www.invest.kielce.pl, Centrum Business in Małopolska, http:// businessinmalopolska.pl, Urzad Marszałkowski Województwa Śląskiego, Wydział Gospodarki, Turystyki i Sportu, Śląskie Centrum Obsługi Inwestora i Eksportera, http://www.invest-in-silesia.pl, Opolskie Centrum Rozwoju Gospodarki, Centrum Obsługi Inwestora i Eksportera http://coi.opolskie.pl, Dolnośląska Agencja Współpracy Gospodarczej Sp. z. o. o., Dolnośląskie Centrum Obsługi Inwestora i Eksportera DAWG http://dawg.pl/, Urząd Marszałkowski Województwa Lubuskiego, Departament Przedsiębiorczości i Strategii Marki, Centrum Obsługi Inwestora http://www.coi-lubuskie.pl, Urząd Marszałkowski Województwa Zachodniopomorskiego, Centrum Obsługi Inwestorów i Eksporterów www.coi.wzp.pl/, Invest in Pomerania http://www. investinpomerania.pl, Warmińsko-Mazurska Agencja Rozwoju Regionalnego S. A. w Olsztynie, Warmińsko-Mazurskie Centrum Obsługi Inwestora http://www.investinwarmiaandmazury.pl, Urząd Marszałkowski Województwa Kujawsko-Pomorskiego, Kujawsko-Pomorskie Centrum Obsługi Inwestora www.coi.kujawsko-pomorskie.pl, Stowarzyszenie Gmin i Powiatów Wielkopolski, Centrum Obsługi Inwestora www.investinwielkopolska. pl/, Urząd Marszałkowski Województwa Łódzkiego, Departament ds. Przedsiębiorczości, Wydział - Regionalne Centrum Obsługi Inwestora i Eksportera http://www.investin.lodzkie.pl, Agencja Rozwoju Mazowsza S.A., Centrum Obsługi Inwestora i Eksportera coie.armsa.pl/ (dostęp: 20.12.2015). 
Diversity of names of individual RCOIs was identified, as well as the lack of unification of their websites and information published there. Freedom is shaping RCOI websites was observed, both regarding their contents and their graphical layout.

The results of the study has shown that the websites of the analyzed institutions constituted the source of regional information, laws and regulations, investment offers, current data about the economy of the region, as well as investment incentives and tax credits, needed by investors. The offer of the part of the surveyed institutions also included accepting and supporting incoming and outgoing economic missions, as well as assisting investors in dealing with the local government, business environment institutions and business partners. The websites of some RCOIs also offer guides for investors, containing, among others, information on establishing and conducting various forms of business in Poland, obtaining necessary licenses and permits, the labour law, taxes, etc. Some of the websites also contained information about investor supporting institutions operating in the province, including parks. Of vital importance was the fact of placing a database/search engine of investment offers on all of the RCOI websites, which was a great convenience for potential investors. Databases of investment offers usually allowed to be searched by offers with division into greenfields and brownfields, and sometimes also office areas, production halls, and privatisation offers. The databases differed among themselves by supplementary criteria, by which they could be searched, i.e.: area, distance from a motorway, national road, railway station, airport, seaport, border crossing, Special Economic Zone, Technology Park, land use in local land-use plans. ${ }^{8}$ The presented RCOI offer contributes to the achievement of the investors' objectives by providing necessary information and assistance in dealing with various partners, which has a positive effect on potential investment attractiveness of regions.

Regional Investor Service Centres also took measures to promote investment offer of individual municipalities and counties overseas, e.g. by participating in the events of an investment \& economical nature. The post-investment care was also of importance, which in the Śląskie province included, among others: support in the recruitment of employees and organization of training courses, provision of information about local suppliers, assistance in finding investment areas in case of the company's spatial expansion, and promotion of export. ${ }^{9}$ These actions contribute to shaping the actual investment attractiveness of the region.

In addition to the RCOI network, there is also a network of Investors and Exporters' Service Centres (COIE) operating in Poland. It is a project co-financed

\footnotetext{
${ }^{8}$ Search engines provided on the websites of the Slaskie and Warmiński-Mazurskie provinces deserve a distinction, as they enable searching the database using the biggest number of criteria.

${ }^{9}$ Dolnoślaska Agencja Współpracy Gospodarczej Sp. z. o. o. [Lower Silesian Agency of Economic Cooperation], Dolnośląskie Centrum Obsługi Inwestora i Eksportera DAWG [Lower Silesian Centre for Investor and Exporter Service DAWG] http://dawg.pl/ [accessed: 20.12.2015].
}

potencjalnych inwestorów. Bazy ofert inwestycyjnych z reguły umożliwiają ich przeszukiwanie z podziałem na oferty greenfields lub brownfields, niekiedy również powierzchnie biurowe, hale produkcyjne, czy oferty prywatyzacyjne. Bazy różnią się pomiędzy sobą dodatkowymi kryteriami, według których można je przeszukiwać, tj. m.in.: powierzchnia, odległość od autostrady, drogi krajowej, stacji kolejowej, lotniska, portu morskiego, przejścia granicznego, Specjalna Strefa Ekonomiczna, Park Technologiczny, przeznaczenie terenu w lokalnych planach zagospodarowania przestrzennego. ${ }^{8}$ Zaprezentowana oferta RCOI przyczynia się do osiągania celów inwestorów poprzez dostarczanie potrzebnych informacji oraz pomoc w kontaktach z różnymi partnerami, co wpływa pozytywnie na potencjalną atrakcyjność inwestycyjną regionów.

Regionalne Centra Obsługi Inwestora podejmują również działania mające na celu promocję za granicą oferty inwestycyjnej poszczególnych gmin i powiatów z województwa, np. poprzez udział w wydarzeniach o charakterze inwestycyjno - gospodarczym. Istotne znaczenie ma również opieka poinwestycyjna, która w województwie dolnośląskim obejmuje m.in.: wsparcie w zakresie rekrutacji pracowników i organizacji szkoleń, wskazanie lokalnych dostawców, pomoc w wyszukaniu terenów inwestycyjnych w sytuacji ekspansji przestrzennej firmy oraz promocję eksportu. ${ }^{9}$ Działania te przyczyniają się do kształtowania rzeczywistej atrakcyjności inwestycyjnej regionu.

Oprócz sieci RCOI w Polsce funkcjonuje również sieć Centrów Obsługi Inwestorów i Eksporterów (COIE). Jest to projekt współfinansowany ze środków Europejskiego Funduszu Rozwoju Regionalnego oraz Programu Operacyjnego Innowacyjna Gospodarka. Celami projektu jest m.in. wzrost poziomu umiędzynarodowienia polskich firm oraz zwiększanie poziomu inwestycji zagranicznych w Polsce poprzez ułatwienie potencjalnym inwestorom zagranicznym dostępu do informacji o warunkach podejmowania działalności gospodarczej w Polsce i instrumentach wsparcia rozwoju przedsiębiorczości, w tym zachętach inwestycyjnych. ${ }^{10}$

Można zauważyć trend do integrowania informacji dla inwestorów oraz eksporterów $\mathrm{w}$ ramach jednej strony internetowej, zawierającej odpowiednie zakładki dla tych dwóch grup przedsiębiorców. W niektórych przypadkach zauważono również wyraźnie wyodrębnioną strefę samorządów (np. w województwie śląskim, opolskim, warmińsko-mazurskim i wielkopolskim), z której mogą skorzystać gminy zainteresowane zamieszczeniem w bazie ofert inwestycyjnych ze swojego terenu. W tym kontekście jako przykład dobrych praktyk

\footnotetext{
${ }^{8}$ Na wyróżnienie zasługują wyszukiwarki zamieszczone na stronach internetowych w województwie śląskim oraz warmińsko-mazurskim dające możliwość przeszukiwania baz danych według największej liczby kryteriów.

9 Dolnośląska Agencja Współpracy Gospodarczej Sp. z. o. o., Dolnośląskie Centrum Obsługi Inwestora i Eksportera DAWG http:// dawg.pl/, (dostęp: 20.12.2015)

10 Ministerstwo Rozwoju, https://www.mr.gov.pl/strony/uslugi/ odwiedz-centra-obslugi-inwestorow-i-eksporterow/, (dostęp 04.04.2016).
} 
by the European Regional Development Fund and the Operational Programme Innovative Economy. The goals of the project include, among others, increasing the level of internationalization of Polish companies and increasing the level of foreign investments in Poland by facilitating potential foreign investors to access information on the conditions of making business in Poland and the instruments to support the development of entrepreneurship, including investment incentives. ${ }^{10}$

There is a trend to integrate information for investors and exporters within a single website, using tabs for each of these two groups of entrepreneurs. In some cases, a distinctly separate zone of selfgovernments was identified (e.g. in the Śląskie, Opolskie, Warmińsko-Mazurskie and Wielkopolskie provinces), from which can benefit the municipalities interested in placing investment offers from their area in the database. In this context, the information posted on the websites of the Warmia \& Mazury ${ }^{11}$ and Wielkopolska Investor Service Centres ${ }^{12}$ can be quoted as an example of best practices. A tool is placed there for collecting information about a given municipality's investment offer, in the form of a so called Site check list form, describing individual elements of a specific offer. Moreover, on the website of the Warmia and Mazury Investor Service Centre additional forms were placed, intended to collection information about office areas, the investment project offered (e.g. executed under the public-private partnership), and a form to submit a cooperation offer (for both self-government bodies and entrepreneurs).

\section{Conclusions}

The aim of this article was to identify and assess the role of business environment institutions in shaping the investment attractiveness of regions. Special attention has been given to park institutions and Regional Investor Service Centres. I has been proven in the course of the research that BEIs are an important factor affecting the potential investment attractiveness. For the presence and quality of institutions affect the opportunity to acquire, store, transform and share knowledge. Institutional coverage of the regions also contributes to the creation of cooperation networks, including the formation of cluster initiatives.

It has been determined in the course of the analysis that there is a dependency between institutional resources of the region and its actual attractiveness. It is connected to, among others, the activity aimed at promoting investments. Whereas, of particular

\footnotetext{
${ }^{10}$ Ministerstwo Rozwoju [Ministry of Development], https://www. $\mathrm{mr}$. gov.pl/strony/uslugi/odwiedz-centra-obslugi-inwestorow-ieksporterow/, [accessed: 04.04.2016].

${ }^{11}$ Warmińsko-Mazurska Agencja Rozwoju Regionalnego S. A w Olsztynie [Warmia and Mazury Regional Development Agency in Olsztyn], Warmińsko-Mazurskie Centrum Obsługi Inwestora [Warmia and Mazury Investor Service Centre] http://www. investinwarmiaandmazury.pl, (accessed: 20.12.2015).

${ }^{12}$ Stowarzyszenie Gmin i Powiatów Wielkopolski [Association of Wielkopolska Municipalities and Counties], Centrum Obsługi Inwestora [Investor Service Centre] www.investinwielkopolska. $\mathrm{pl} /$, (accessed: 20.12.2015)
}

można wskazać informacje zamieszczone na stronach internetowych warmińsko-mazurskiego ${ }^{11}$ oraz wielkopolskiego Centrum Obsługi Inwestora ${ }^{12}$. Zamieszczono tu narzędzie służące do zbierania informacji na temat oferty inwestycyjnej gmin w postaci tzw. formatki Site check list opisującej poszczególne elementy konkretnej oferty. Ponadto na stronie internetowej Warmińsko-Mazurskiego Centrum Obsługi Inwestora zamieszczono dodatkowo formatki majace na celu zbieranie informacji dotyczacych powierzchni biurowych, oferowanego projektu inwestycyjnego (np. realizowanego $\mathrm{w}$ ramach partnerstwa publiczno-prywatnego), a także formularz zgłoszenia oferty współpracy (przeznaczony zarówno dla jednostek samorządu terytorialnego jak i przedsiębiorców).

\section{Podsumowanie}

Celem niniejszego artykułu była identyfikacja i ocena roli instytucji otoczenia biznesu w kształtowaniu atrakcyjności inwestycyjnej regionów. W sposób szczególny badaniom poddano instytucje parkowe oraz Regionalne Centra Obsługi Inwestora. W toku badań wykazano, że IOB stanowią ważny czynnik wpływający na potencjalną atrakcyjność inwestycyjną. Obecność i jakość instytucji wpływa bowiem na możliwości pozyskiwania, przechowywania, przekształcania i dzielenia się wiedzą. Wyposażenie instytucjonalne regionów przyczynia się także do tworzenia sieci współpracy, w tym do powstawania inicjatyw klastrowych.

W toku analiz stwierdzono, że istnieje zależność pomiędzy zasobami instytucjonalnymi regionu a jego atrakcyjnością rzeczywistą. Jest ona związana m.in. $\mathrm{z}$ działalnością mająca na celu promocje inwestycji. Przy czym ważne znaczenie dla jej efektywności ma potrzeba precyzyjnego i zindywidualizowanego ukierunkowania inicjatyw promocyjnych.

Należy również zauważyć, że do czynników wpływających na podjęcie decyzji dotyczącej internacjonalizacji działalności można zaliczyć elementy sta-

\footnotetext{
${ }^{11}$ Warmińsko-Mazurska Agencja Rozwoju Regionalnego S. A. w Olsztynie, Warmińsko-Mazurskie Centrum Obsługi Inwestora http://www.investinwarmiaandmazury.pl, (dostęp: 20.12.2015)

12 Stowarzyszenie Gmin i Powiatów Wielkopolski, Centrum Obsługi Inwestora www.investinwielkopolska.pl/, (dostęp: 20.12.2015).
} 
significance to its effectiveness is the need for precise and individualized targeting of promotional initiatives.

It should also be noted that the factors influencing the decision on the internationalization of operations include the elements constituting the domain of activity of business environment institutions.

The impact of business environment institutions on the investment attractiveness depends on many factors, including the specifics of the region, type of business, size of the project or the current phase of the economy's development. An important role is played by the targeting of the BEIs' offer towards realization of the support tailored to the needs of enterprises operating in the region, as well as their expected development path, identified e.g. on the basis of strategic documents, regional smart specializations, etc.

The activity of the state and local government bodies contributes to the creation of new institutional structures which may affect the growth of the investment attractiveness of a particular area. The particular importance is attributed to actions aimed at stimulating pro-innovation activities of enterprises. The research on the institutional support of entrepreneurs across the Polish provinces has showed the lack of regional diversity of service portfolios presented on the business environment institutions' websites. The service portfolio of Parks (technology, science \& research, industry, investment parks) has been recognized as the most comprehensive in regard to the support of entrepreneurs. The tendency has been proven to link the Parks' offer with the benefits of operating in Special Economic Zones, the operation of (technology and entrepreneurship) incubators, clusters, research laboratories, and Data Centres. One can notice a trend of combining several additional functions within the Parks (the most common is the inclusion of investment areas into Special Economic Zones along with the ability to take advantage of the Incubator's offer).

For investors, a particularly significant form of support is the network of Regional Investor Service Centres, offering a comprehensive service for investors at every stage of the investment process, as well as the network of Investors and Exporters' Service Centres (COIE). Information services and partner-matching services, offered by RCOI, contribute positively to the development of potential investment attractiveness of the regions. The activity of these institutions in the field of the promotion of investment offers of municipalities and counties of the province, as well as post-investment care of businesses constitutes a factor of the actual investment attractiveness of the regions. nowiące domenę działalności instytucji otoczenia biznesu.

Wpływ instytucji otoczenia biznesu na atrakcyjność inwestycyjną zależy od wielu czynników, m.in. od specyfiki regionu, rodzaju działalności gospodarczej, wielkości przedsięwzięcia czy fazy rozwoju gospodarki. Istotna rolę odgrywa ukierunkowanie oferty IOB na realizację wsparcia dostosowanego do potrzeb przedsiębiorstw działających $\mathrm{w}$ regionie, a także jego przewidywanej ścieżki rozwojowej, identyfikowanej np. na podstawie dokumentów strategicznych, regionalnych inteligentnych specjalizacji, itp.

Działalność państwa i JST przyczynia się do tworzenia nowych struktur instytucjonalnych, które moga wpływać na wzrost atrakcyjności inwestycyjnej danego terenu. Szczególnie ważne są działania mające na celu stymulowanie proinnowacyjnych działań przedsiębiorstw. Badania dotyczace wsparcia instytucjonalnego przedsiębiorców $\mathrm{w}$ polskich województwach wykazały brak zróżnicowania regionalnego oferty prezentowanej na stronach internetowych instytucji okołobiznesowych. Oferta Parków (technologicznych, naukowo-badawczych, przemysłowych, inwestycyjnych) została uznana za najbardziej kompleksową w zakresie wsparcia przedsiębiorców. Wykazano tendencję łączenia oferty Parków z korzyściami działania w ramach SSE, funkcjonowaniem inkubatorów (technologicznych i przedsiębiorczości), klastrów, laboratoriów badawczych, czy Data Center. Zauważalny jest trend łączenia w ramach Parków kilku dodatkowych funkcji (najczęściej spotykane jest włączanie terenów inwestycyjnych w obszar SSE wraz z możliwością skorzystania z oferty Inkubatora).

Dla inwestorów szczególnie ważnym wsparciem jest sieć Regionalnych Centrów Obsługi Inwestora oferujących kompleksową obsługę inwestora na każdym etapie prowadzenia inwestycji, a także sieć Centrów Obsługi Inwestorów i Eksporterów (COIE). Usługi informacyjne oraz w zakresie kojarzenia partnerów oferowane przez RCOI przyczyniają się pozytywnie do kształtowania potencjalnej atrakcyjności inwestycyjnej regionów. Działalność omawianych instytucji w zakresie promocji oferty inwestycyjnej gmin i powiatów z terenu województwa, a także w zakresie obsługi poinwestycyjnej podmiotów gospodarczych stanowi czynnik rzeczywistej atrakcyjności inwestycyjnej regionów.

\section{References/ Literatura:}

1. Active policies for attracting foreign direct investment: international experiences and the situation in Latin America and the Caribbean (2007), W: Foreign Investment in Latin America and the Caribbean 2006. Economic Commission for Latin America and the Caribbean (ECLAC), Santiago, Chile.

2. Bański J. (2015), Rola instytucji otoczenia biznesu w rozwoju przedsiębiorczości wiejskiej. Wieś i Rolnictwo, nr 2 (167), p. 139149.

3. Dorożyński T., Urbaniak W. (2011), Rola instytucji otoczenia biznesu we wspieraniu inwestorów zagranicznych w województwie łódzkim, W: J. Świerkocki (red.), Rola bezpośrednich inwestycji zagranicznych w kształtowaniu aktualnego i przyszłego profilu gospodarczego województwa łódzkiego, Łódzkie Towarzystwo Naukowe, Łódź, s. 187-200. 
4. Dunning J.H. (2002), Theories and Paradigms of International Business Activity: The Selected Essays of John H. Dunning. Volume 1, Edward Elgar, Cheltenham.

5. Exchange of Good Practice in Foreign Direct Investment Promotion. A study carried out under the Framework Contract ENTR/2009/033. Final report - 2nd revision. (2013), ECORYS, Rotterdam.

6. Gawlikowska-Hueckel K., Umiński S. (2000), Ocena konkurencyjności województw. Polska Regionów nr 12, s. 65.

7. Godlewska-Majkowska H. (red.) (2008), Atrakcyjność inwestycyjna polskich regionów. W poszukiwaniu nowych miar. Studia i analizy Instytutu Przedsiębiorstwa Oficyna Wydawnicza SGH, Warszawa.

8. Godlewska-Majkowska H., Komor A. (2014), Regionalna konkurencyjność jako czynnik rozwoju biogospodarki, W: H. Godlewska-Majkowska, A. Buszko (red.), Uwarunkowania rozwoju biogospodarki na przykładzie województwa warmińsko-mazurskiego. Oficyna Wydawnicza, Szkoła Główna Handlowa w Warszawie, Warszawa, s. 46-60.

9. Goetz M. (2006), Atrakcyjność klastrów dla bezpośrednich inwestycji zagranicznych (BIZ). International Journal of Management and Economics, 20, s. 8-23.

10. Guimón J. (2008), Government strategies to attract R\&D-intensive FDI. OECD, VII Global Forum on International Investment, Paris.

11. Jankowiak A.H. (2014), Lokalizacja w klastrze jako motyw internacjonalizacji przedsiębiorstw. Prace Naukowe Uniwersytetu Ekonomicznego we Wrocławiu, nr 369, s. 263-271.

12. Mikuła B. (2006), Organizacje oparte na wiedzy. Wydawnictwo Akademii Ekonomicznej w Krakowie, Kraków.

13. Poskrobko B. (2008), Rola samorządów terytorialnych w kształtowaniu kapitału ludzkiego na potrzeby gospodarki opartej na wiedzy. Optimum - Studia Ekonomiczne, nr 4 (40), s. 93-108.

14. Rosińska M. (2007), Kierunki globalnych przepływów kapitałowych a znaczenie miękkich czynników lokalizacji bezpośrednich inwestycji zagranicznych $w$ procesie decyzyjnym, W: W. Karaszewski (red.), Bezpośrednie inwestycje zagraniczne w budowaniu potencjału konkurencyjnego przedsiębiorstw i regionów. Wydawnictwo Uniwersytetu Mikołaja Kopernika w Toruniu, Toruń, s. 307-322.

15. Rozporzqdzenie Ministra Rozwoju Regionalnego z dnia 20 maja 2009 r. w sprawie udzielania pomocy na wzmacnianie potencjału instytucji otoczenia biznesu w ramach regionalnych programów operacyjnych, Dz.U. $2009 \mathrm{nr} 85$ poz. $719 . /$ Regulation of the Minister of Regional Development of 20 May 2009 on assistance to strengthen the potential of business environment institutions under regional operational programs, Journal of Laws [Dz.U.] of 2009, no. 85, item 719.

16. The Knowledge-Based Economy. (2006), OECD, Paris.

17. Tödtling F., Asheim B., Boschma R. (2013), Knowledge sourcing, innovation and constructing advantage in regions of Europe. European Urban and Regional Studies, 20 (2), s. 161-169.

18. Tödtling F., Skokan K., Höglinger Ch., Rumpel P., Grillitsch M. (2013), Innovation and knowledge sourcing of modern sectors in old industrial regions: comparing software firms in Moravia-Silesia and Upper Austria. European Urban and Regional Studies, 20 (2), p. 188-205.

19. Woźniak-Miszewska M. (2011), Motywy bezpośrednich inwestycji zagranicznych w zachodniopomorskiem. Zeszyty Naukowe Uniwersytetu Szczecińskiego nr 683. Ekonomiczne Problemy Usług, 77, p. 364-378.

20. Zvirgzde D., Schiller D., Revilla Diez J. (2013), Location choices of multinational companies in transition economies: A literature review, Search Working paper 2/05.

\section{Websites/ Strony internetowe:}

21. Agencja Rozwoju Mazowsza S.A. [Mazovia Development Agency], Centrum Obsługi Inwestora i Eksportera [Centre for Investor and Exporter Service] coie.armsa.pl/, (data dostępu: 20.12.2015).

22. Bełchatowsko Kleszczowski Park Przemysłowo Technologiczny Sp. z o.o. [Bełchatów-Kleszczów Industry and Technology Park] http://www.ppt.belchatow.pl/, (data dostępu: 15.12.2015).

23. Białogardzki Park Inwestycyjny “Invest-Park" Sp. z o.o. [“Invest-Park” Investment Park in Białogard] http://www.investpoland.info, [accessed: 15.12.2015].

24. Białostocki Park Naukowo - Technologiczny [Science and Technology Park in Białystok] www.bpnt.bialystok.pl, (data dostępu: 15.12.2015).

25. Bydgoski Park Przemysłowo-Technologiczny [Industry and Technology Park in Bydgoszcz] www.bppt.pl, (data dostępu: 15.12.2015).

26. Centrum Business in Małopolska [Business in Małopolska Centre], http://businessinmalopolska.pl, (data dostępu: 20.12.2015).

27. Dolnośląska Agencja Współpracy Gospodarczej Sp. z. o. o. [Lower Silesian Agency of Economic Cooperation], Dolnośląskie Centrum Obsługi Inwestora i Eksportera DAWG [Lower Silesian Centre for Investor and Exporter Service DAWG] http:// dawg.pl/ (data dostępu: 20.12.2015).

28. Dolnośląski Park Innowacji i Nauki [Dolnośląskie Innovation and Science Park] www.dpin.pl, (data dostępu: 15.12.2015).

29. Gdański Park Naukowo-Technologiczny [Science and Technology Park in Gdańsk] www.gpnt.pl, (data dostępu: 15.12.2015).

30. Goleniowski Park Przemysłowy [ndustrial Park in Goleniów] http://goleniow.biz/, (data dostępu: 15.12.2015).

31. Invest in Pomerania http://www.investinpomerania.pl, (data dostępu: 20.12.2015).

32. Kędzierzyńsko - Kozielski Park Przemysłowy [Industrial Park in Kędzierzyn-Koźle] www.kkpp.pl, (data dostępu: 15.12.2015)

33. Kielecki Park Technologiczny [Technology Park in Kielce] http://www.technopark.kielce.pl/, (data dostępu: 15.12.2015).

34. Krakowski Park Technologiczny Sp. z o.o. [Technology Park in Kraków] www.sse.krakow.pl, (data dostępu: 15.12.2015).

35. Legnicki Park Technologiczny LETIA S.A. [LETIA Technology Park in Legnica] www.letia.pl, (data dostępu: 15.12.2015).

36. Łódzki Regionalny Park Naukowo-Technologiczny Sp. z o.o. [Regional Science and Technology Park in Łódź] http://www. technopark.lodz.pl/, (data dostępu: 15.12.2015).

37. Ministerstwo Rozwoju [Ministry of Development], https://www.mr.gov.pl/strony/uslugi/odwiedz-centra-obslugi-inwestorow-i-eksporterow/, (data dostępu: 04.04.2016).

38. Olsztyński Park Naukowo-Technologiczny [Science and Technology Park in Olsztyn] http://opnt.olsztyn.pl/, (data dostępu: 15.12.2015) 
39. Opolskie Centrum Rozwoju Gospodarki [The Opolskie Province’s Centre for Economic Development], Centrum Obsługi Inwestora i Eksportera [Investor and Exporter Service Centre] http://coi.opolskie.pl, (data dostępu: 20.12.2015).

40. Park Naukowo - Technologiczny Polska - Wschód w Suwałkach Sp. z o.o. [Poland-East Science and Technology Park in Suwałki] www.park.suwalki.pl, (data dostępu: 15.12.2015).

41. Park Naukowo-Technologiczny Uniwersytetu Zielonogórskiego w Nowym Kisielinie [Science and Technology Park of the University of Zielona Góra in Nowy Kisielin] www.pnt.uz.zgora.pl, (data dostępu: 15.12.2015).

42. Park Naukowo-Technologiczny w Ełku [Science and Technology Park in Ełk] http://www.technopark.elk.pl/, (data dostępu: 15.12.2015).

43. Park Technologiczny INTERIOR w Nowej Soli [INTERIOR Technology Park in Nowa Sól] http://www.interiorns.pl/, (data dostępu: 15.12.2015).

44. Podkarpacki Park Naukowo-Technologiczny AEROPOLIS [Podkarpackie Science and Technology Park AEROPOLIS] www. aeropolis.com.pl, (data dostępu: 15.12.2015).

45. Polska Agencja Informacji i Inwestycji Zagranicznych [Polish Information and Foreign Investment Agency] http://www. paiz.gov.pl/regiony/coi, (data dostępu: 04.04.2016).

46. Poznański Park Naukowo-Technologiczny Fundacji Uniwersytetu im. Adama Mickiewicza [Science and Technology Park of the Adam Mickiewicz Foundation in Poznań] www.ppnt.poznan.pl, (data dostępu: 15.12.2015).

47. Poznański Park Technologiczno - Przemysłowy [Technology and Industry Park in Poznań] www.pptp.pl, (data dostępu: 15.12.2015).

48. Puławski Park Naukowo-Technologiczny [Science and Technology Park in Puławy] www.ppnt.pulawy.pl, (data dostępu: 15.12.2015).

49. Rzeszowska Agencja Rozwoju Regionalnego S.A. [Rzeszów Regional Development Agency], Centrum Obsługi Inwestora [Investor Service Centre] http://www.coi.rzeszow.pl, (data dostępu: 20.12.2015).

50. Stowarzyszenie Gmin i Powiatów Wielkopolski [Association of Wielkopolska Municipalities and Counties], Centrum Obsługi Inwestora [Investor Service Centre] www.investinwielkopolska.pl/, (data dostępu: 20.12.2015).

51. Śląski Park Przemysłowo-Technologiczny w Rudzie Śląskiej [Śląskie Industry and Technology Park in Ruda Śląska] http:// sppt.pl/, (data dostępu: 15.12.2015).

52. Tarnobrzeski Park Przemysłowo-Technologiczny [Industry and Technology Park in Tarnobrzeg] www.tppt.tarnobrzeg.pl, (data dostępu: 15.12.2015).

53. Toruński Park Technologiczny [Technology Park in Toruń] www.technopark.org.pl, (data dostępu: 15.12.2015).

54. Urząd Marszałkowski Województwa Kujawsko-Pomorskiego [Marshal’s Office of the Kujawsko-Pomorskie Province], Kujawsko-Pomorskie Centrum Obsługi Inwestora [Investor Service Centre of the Kujawsko-Pomorskie Province] www.coi. kujawsko-pomorskie.pl, (data dostępu: 20.12.2015).

55. Urząd Marszałkowski Województwa Lubelskiego w Lublinie [Marshal's Office of the Lubelskie Province in Lublin], Departament Gospodarki i Współpracy Zagranicznej [Department of Economy and International Cooperation] http://www.invest. lubelskie.pl/pl, (data dostępu: 20.12.2015).

56. Urząd Marszałkowski Województwa Lubuskiego [Marshal's Office of the Lubuskie Province], Departament Przedsiębiorczości i Strategii Marki [Department of Enterprise and Brand Strategy], Centrum Obsługi Inwestora [Investor Service Centre] http://www.coi-lubuskie.pl, (data dostępu: 20.12.2015).

57. Urząd Marszałkowski Województwa Łódzkiego [Marshal's Office of the Łódzkie Province], Departament ds. Przedsiębiorczości [Department of Enterprise], Wydział - Regionalne Centrum Obsługi Inwestora i Eksportera [Division - Regional Centre for Investor and Exporter Service] http://www.investin.lodzkie.pl, (data dostępu: 20.12.2015).

58. Urząd Marszałkowski Województwa Podlaskiego [Marshal’s Office of the Podlaskie Province], Centrum Obsługi Inwestora [Investor Service Centre] / Centrum Obsługi Inwestorów i Eksporterów [Service Centre for Investors and Exporters] http:// coi.wrotapodlasia.pl, (data dostępu: 20.12.2015).

59. Urząd Marszałkowski Województwa Śląskiego [Marshal’s Office of the Śląskie Province], Wydział Gospodarki, Turystyki i Sportu [Department of Economy, Tourism and Sport], Śląskie Centrum Obsługi Inwestora i Eksportera [The Śląskie Province's Service Centre for Investors and Exporters], http://www.invest-in-silesia.pl, (data dostępu: 20.12.2015).

60. Urząd Marszałkowski Województwa Zachodniopomorskiego [Marshal's Office of the Zachodniopomorskie Province], Centrum Obsługi Inwestorów i Eksporterów [Service Centre for Investors and Exporters] www.coi.wzp.pl/, (data dostępu: 20.12.2015).

61. Urząd Miasta Kielce [Kielce City Office], Wydział Rozwoju i Rewitalizacji Miasta [Department of Development and Revitalization of the City], Centrum Obsługi Inwestora [Investor Service Centre], http://www.invest.kielce.pl, (data dostępu: 20.12.2015).

62. Warmińsko-Mazurska Agencja Rozwoju Regionalnego S. A. w Olsztynie [Warmia and Mazury Regional Development Agency in Olsztyn], Warmińsko-Mazurskie Centrum Obsługi Inwestora [Warmia and Mazury Investor Service Centre] http://www. investinwarmiaandmazury.pl, (data dostępu: 20.12.2015). 